\title{
DIGITAL RESPONSE TO COVID-19 INFECTED ECONOMY: A EUROPEAN UNION PERSPECTIVE
}

\author{
Ceran ARSLAN OLCAY* \\ Özlem GENÇ** \\ Araştırma Makalesi
}

\begin{abstract}
Since January 2020, the world has been experiencing an unexpected pandemic which has affected people around the world both economically and socially. Mostly the demands of people, for goods and services were provided through online shopping; besides, working from home, public \& private transactions were made possible by digital opportunities. Now, we are experiencing the time for testing digital instruments for economic recovery. In this study, response and potential of digitization for economic recovery will be assessed by taking the European Union (EU) case. As a response to the crisis, the EU has prioritized digitization as a tool for recovering from economic effects of COVID 19. In this study, the approach of the EU for the mitigation of "COVID infected" economy will be evaluated.
\end{abstract}

Keywords: Digital Economy, Digital Europe, European Union, COVID 19, Economic Recovery.

\section{Covid-19 Bulaşan Ekonomiye Dijital Cevap: Avrupa Birliği Perspektifi}

$\ddot{O} z$

2020'nin başından beri, dünyanın pandemi süreci içerisine girmesi, sağlık problemlerinin yanısıra, ekonomik ve sosyal etkilerin de ortaya çıkmasına yol açmıştır. Değişen hayat tarzları, uzaktan çalışma zorunluluğu, istihdam kayıpları hem, hanehalkları hem de firmaları ve hatta toplam talep ve arzı negatif yönde

* Dr. Öğr. Üyesi, Ankara Üniversitesi Siyasal Bilgiler Fakültesi, İktisat Bölümü, E-posta: ceranarslanolcay@gmail.com, ORCID: 0000-0002-2114-4076.

** Dr. Arş. Gör. Ankara Üniversitesi Siyasal Bilgiler Fakültesi, Maliye Bölümü, E-posta: Ozlem.Genc@law.ankara.edu.tr, ORCID: 0000-0001-6253-1120.

Makalenin Gönderilme Tarihi: 23/10/2020 Kabul Edilme Tarihi: 01/02/2021 
etkilemiştir. Bu süreçte, özellikle mal ve hizmetlerin temini, uzaktan çalışabilme, kamusal ve özel tüm işlemler, dijital imkanlarla mümkün hale gelmiştir. Dijitalleşmenin, bu günlerin ekonomik açıdan iyileşmesine katkusının test edildiği günlerden geçiyoruz. Bu çalışmada, Avrupa Birliği (AB) örneği ele alınarak, dijitalleşmenin ekonomik iyileşmeye katklst ve potansiyeli incelenecektir. AB, COVID 19'un ekonomik etkilerinin yol açttğı hasardan kurtulmak için dijitalleşmeyi öncelik haline getirmiştir. DESI çerçevesinde AB ülkelerinin dijitalleşme düzeylerinin incelenmesi ve Avrupa Birliği'nin enfekte ekonomi üzerindeki etkileri ile mücadele etmek üzere tercih ettiği yaklaşım değerlendirilecektir.

Anahtar Kelimeler: Dijital Ekonomi, Dijital Avrupa, COVID 19, Avrupa Birliği, Ekonomik İileşme.

\section{Introduction}

The year 2020 marks the date of COVID 19 becoming pandemic and ripping through the global economy. World had experienced several global crises emanating either from pandemics such as Spanish influenza, Ebola, SARS $^{1}, \mathrm{MERS}^{2}$, etc. or from economic shocks such as Great Depression, two world wars taking place in $20^{\text {th }}$ century, Oil Shocks of 1970 s and global financial crisis of 2008. COVID 19 is considered to be the worst combining the effects of pandemics and other economic shocks. Mass unemployment and bankruptcies have been the consequences; bail-outs have been started to get the economy back on track as world economies have been familiar with since the global crisis of 2008. When the COVID 19 has spread all over the world, the world was under the circumstances constituted by the 2008 global crisis.

The 2008 global crisis has been a trigger of change in all over the world and re-organized the economic structures. Starting from the 1990's, world has been experiencing an era of interbedded hyper-globalization and digitization processes but the depression after 2008 global financial crisis has slowed down the hyper-globalization. Just after the global crisis, 2012 Euro debt crisis has caused a greater uncertainty in economic conditions rising World Uncertainty Index (WUI) by $200 \%$. Since then, usage of digital ${ }^{3}$ opportunities mostly in global value chains $(\mathrm{GVC})$ have started to be

Severe Acute Respiratory Syndrome.

Middle East Respiratory Syndrome.

3 "Digital" is a terminology describing the intensity of information and interactivity between the physical objects. Things become digital with the use of digital technologies to give and share information about themselves. This intensity is important for transforming the businesses to new digital business models with the aim of finding sustainable sources of income and added value for the requirements of the digital economy (Marinko,Wilko, 
a recovery tool in various platforms for economic transactions, manufacturing and commerce. ${ }^{4}$

Now the world is being tested by another economic breakdown leading to breakages in most of the sectors and triggering the global recession. In the 1st quarter of 2020 economies were in free fall going to uncertainty. A challenging, tough period for approximately 6 months with the contagion of China originated COVID 19 has been mortal for a lot of people across the world. It is more hazardous than the flu we all get used to facing with and has been declared by the World Health Organization (WHO) as "pandemic".

Slowing down hit services the hardest, then came the supply chains strained with the decrease in aggregate demand. Especially shut down of the sectors involving personal contact, left many workers jobless and ended up in a big income loss and decrease in aggregate demand. The shocks rising after COVID 19 mostly disrupted global supply chains, caused consumer demand shock and had negative impact on sectors such as transport, entertainment, gastronomy, tourism and so on. Certainly, the pandemic has mostly affected the health sector, social and professional lives of people, moreover it has biased the economies of households, firms and states, in other words wreaked havoc all the sectors. ${ }^{5}$ Now, although the restrictions are kept minimized, the demand for most of the service sectors is low unless they are vital needs. So, it is very clear that the pandemic combines also supply shocks which reduce the economy's capacity to produce goods and services at given prices. Social distancing induces a supply shock by preventing workers and owners from producing services as much as nonpandemic times. A demand shock reduces consumers' demand as a result of preferences, income, changing life conditions at given prices. ${ }^{6}$ Compared with other economic shocks, new types of challenges are being tested. It is very global and world seems much more integrated. Supply chain networks

Lulic, "The Digital Transformation of Croation Economy compared with other EU countries", Preliminary Communication, (2019) :151, Accessed: 10.07.2020, https://search.proquest.com/docview/2422403017?pqorigsite $=$ gscholar\& fromopenview $=$ true

4 Kemal Kilıç, Dalla Marin, "How COVID 19 is transforming the World Economy", (2020), Column 10 May, Accessed: 10.08.2020, https://voxeu.org/article/how-covid-19transforming-world-economy

5 Peterson Ozili, Thankom Arun, "Spillover of COVID 19:impact on the global economy", SSRN Electronic Journal, (2020):6-8, Accessed: 20.07.2020, https://www.researchgate.net/publication/340236487_Spillover_of_COVID19 impact on the Global Economy

6 Pedro Brinca, Joao B.Duarte, Miguel Faria a Casto, Is the Covid 19 Pandemic a suuply or a demand shock? 20.05.2020 : (1-2), Accessed: 10.09.2020, https://papers.ssrn.com/sol3/papers.cfm?abstract_id=3612307 
are one of the tools mostly affected from the COVID 19 and have had wide spillover effects over different suppliers.

An important point to be mentioned is that the closure of borders as a precaution for preventing contagion of the virus added spice to the situation. Fall in the global trade affects both the main exporters and the importers of raw materials. For instance, in the EU; Airbus suspended production in France and Spain, so did car manufacturers. World Trade Organization (WTO) estimates a decline in global trade up to $32 \%$ for $2020 .{ }^{7}$ Also the increasing volatility and instability of the economies lead to a decline in stock markets. Especially U.S and Germany as the two of the biggest economies had the sharpest decline in stock markets, $37 \%$ and $33 \%$ respectively. Yet, the economic impact of COVID 19 can not be estimated exactly. ${ }^{8}$

In short, the rise of the pandemic has mandated people socially distanced for 2-3 months, led to deep uncertainty in consumption trends; layoffs followed at least 6 months (at the time of writing) of slow-down in most of the sectors and decreased the aggregate demand as a consequence of tightening the consumption. Even though life conditions seem turning to normal slowly, the uncertainty in the future scenarios of the pandemic, still paints a blurred vision. Life is still going on-line in most areas. Decrease in aggregate demand is the fundamental reason of decline in economic growth. For example, in the EU; decrease in service demand hit a lot of sectors. Tourism centers such as Paris, Madrid, Rome and Barcelona are deserted. Losses of transportation, tourism, cancellation of events account for a quarter of Italian gross domestic product (GDP). ${ }^{9}$

While sectors have been looking for alternative ways out on the days of lockdown; \#stayathome\# initiative increased the time working at home. Thus brought digital solutions for outdoor activities with it. Both households and firms experienced the advantages of digital opportunities such as ecommerce and digital transactions intensively and have been motivated to strengthen the digital infrastructures.

How will the new normal be shaped during and after COVID 19 period? Responding to new normal requires changes in behaviors to sustain growth. Due to emergency, textiles industry started producing masks, and

7 Nuno Fernandes, "Economic Effects of Coronavirus Outbreak (COVID-19) on the World Economy", March 22, 2020, Accessed:August 2020, https://papers.ssrn.com/sol3/papers.cfm?abstract_id=3557504,

8 Nuno, Fernandes, "Economic Effects of Coronavirus Outbreak", 8

9 Nuno, Fernandes, "Economic Effects of Coronavirus Outbreak", 8 
electronics industry ventilators; cosmetics producers entered the hygienic sanitizer sector. The disruptions in economy have led to searching new ways out.

It is very obvious that the virus has enlarged the digital market and real markets found a ground on digital platforms. This period is the time for growing efforts for economic precautions. For concentrating on recovering economic issues, digitization is unignorable. Digital transformation ${ }^{10}$ has enabled remote working on the days of isolation, in addition e-commerce, robot deliveries, digital payments, digital money, remote education facilities and even home-entertainment systems such as games, live training activities, virtual sightseeing and concerts have eased people's lives. ${ }^{11}$ To illustrate, information technology expenditures are forecasted to grow between $3 \%-5$ $\%$. By 2022, over $60 \%$ of the global economy is expected to be digitalized. ${ }^{12}$

Digitization ${ }^{13}$ is part of our lives and economic activities, smart and data driven economy is opening doors to new (digital) economy which has broad value added on most sectors. ${ }^{14}$ Also, the importance of digitization again came into existence especially in easing life conditions and the recovery of economic slow-down. Will it work again?

It is time to be prepared for the new economic life. Brought about by such challenges, in this paper, future scenarios about digital responses especially for recovery and quick adaptation to the new order will be discussed taking the "EU case" as an example. It is an important block in shaping the global economy which is challenged with pandemic conditions in a hard way. The EU as global power, will be analyzed in the context of digital responses to COVID 19, for recovery and opportunity whether the EU is going to turn this challenge into an opportunity while shaping the digital future.

10 "Changes facilitated by the increased usage of digital opportunies in various field of human activity is defined as "digital transformation". Businesses apply digital technologies and resources in order to create new income sources and business models. It involves changes in operation, roles, and business structures in different levels." (Marinko,Wilko, Lulic,152 ).Integration of new technologies and progressive business concepts, usage of platforms and strong digital models are the key principles of the transformation.

11 Nuno, Fernandes, "Economic Effects of Coronavirus Outbreak", 8

12 UNCTAD, "2019 Report on Digital Economy", (2020):30-33, Accessed: 12.09.2020, https://unctad.org/system/files/official-document/der2019_en.pdf

13 Digitizaiton is a trend terminology like globalization which needs to be managed and governed (European Commission). Challenges rise up from wind of digization which are to be faced by institutions, enterprises and businesses.

14 Nuno, Fernandes, "Economic Effects of Coronavirus Outbreak", 9 


\section{Millennium World, Digitalization and Covid-19}

Industry 4.0 which has paved the way for digitization era in parallel with millennium, has enabled the economic activities being increasingly digital. Releasing of a new research area, "economics of digitization" started to improve the understanding of how and whether the technology changes markets and started to allow for the new outcomes that were not possible a few decades earlier with the increased usage of digital technologies and communication. New digital technologies do not only decrease existing costs via "low marginal costs of production" but also enable the development of new services and processes. As a result, digital market platforms started to provide additional economic growth by expanding markets, creating new jobs by boosting younger and qualified employment and vibrant knowledge based society. So the digital response to COVID 19 is likely to keep its importance for a long time.

Now the disruption in economic life is being tested to be cured by digital supports in order to overcome the period of uncertainty by keeping suppliers and consumers in touch as the breaking of global supply chains is bearing a big risk of stagflation which will eventually be the consequence of a demand shock. The digital response to COVID 19 is an important process for the future of the new normal. Digital opportunities support the society in professional life, government services and shopping under the conditions of quarantine. So, acceleration of digital transformation has been inevitable. People get used to adopting the on-line life into theirs. Period of disruption has been experienced by the entire world and the post corona world is apparently to be reshaped likewise. The world will no doubt be different, even what we eat, how we work, what we buy will be determined accordingly. World economy will mostly be shaped by consumer preferences and changes in demand patterns. Digital networking and managing big data to manage the COVID 19 process will probably create a new global approach which will re-shape human behaviors, technology and industry dynamics, particularly in supply chains.

\section{Milestones of Digitization in EU}

Starting from the 21 st century, breakages in the world economy have been merged with the technological and digital transformation and resulted in new economic structures across the world. Digitization in economic activities has created an opportunity in cost reduction for production, time saving, internet of things to create the tools which can access internet, big data analyses to measure and respond to consumer interests. Thus, digital 
technology is easing the economic growth by using information and technology (I\&T) like e-commerce, data services and industrial infrastructures.

We are experiencing this pandemic in a world, where the global digital transformation is touching every part of our lives. Since spreading of corona virus has been taking a toll on economic players life would have been harder without the new sectors rising from the digitization of the world, some of which have improved to boost economic growth.

The behavior of people getting used to virtual platforms can be traced back to the birth and globalization of Facebook. This development has been a milestone and speeded up digital transactions. By the way this process has overlapped temporally with the recovery efforts in the aftermath of the 2008 global crisis.

\section{A. The EU's Position}

For the last decade EU's solidity has been challenged by crises. Euro crises, refugee crises and ultimately the COVID 19 crisis combining the effects of economic shocks and pandemic. What was widely perceived as "Chinese problem" became "Italian problem" and later on "everybody's problem", especially in EU. COVID-19 crisis is differing with its character from the previous crises as it is a symmetric (emerging from an external shock and affecting the member states in similar ways) shock. ${ }^{15}$ Contraction in the EU GDP is forecasted to decrease by $8,3 \%$ by $2020 .^{16}$

All these challenges are like a reminder of Jean Monnet's saying "People only accept change when they are faced with necessity, and only recognize necessity when a crisis is upon them ${ }^{17}$." Successors of Jean Monnet might have taken into account his saying when they urgently planned a recovery plan in the context of 2021-2027 Multiannual Financial Framework which has to be re-shaped due to the current circumstances. For the structural recovery there are several choices to be adopted; monetary

15 Richard Baldwin, Beatrice de Mauro, edited, "Mitigating the COVID Economic Crises", (2020): 2, Accessed: 15.05.2020, https://www.researchgate.net/publication/342961959_Mitigating_the_COVID_Economic_ Crisis_Act_Fast_and_Do_Whatever_It_Takes_A_VoxEUorg_Book

16 European Commission, "Summer 2020 Economic Forecast", Accessed: 10.08.2020, https://ec.europa.eu/commission/presscorner/detail/en/ip_20_1269

17 European Economic anad Social Committee, "Ask the president", Accessed:11.07.2020, https://www.eesc.europa.eu/en/about/political-organisation/eesc-president/ask-thepresident 
policy, fiscal policy and acceleration of digitization especially for the industrial development, good functioning of the Digital Single Market via Digital Europe. In the era of new economic structures, along with conventional policies, supplementary tools are inevitably manifested. Digitization is the most promising in terms of enhancing growth by enhancing digital transformation level. Does digital transformation level positively affect economic recovery and growth? The answer to this question is also very important for the EU's global future ${ }^{18}$.

It is very clear that the EU as a global actor is aiming to build a global digital model for the digital economy. So supporting economies going digital and improving the digitization phases are essential. The point is to clarify the supporting effects of digital transformation in this period.

Europe has a strong position in certain sectors, especially the digitalization of industry, such as photonic or robotics, but still lagging behind the United States of America (USA) and China in figures. In 2015 statistics, $20 \%$ of the global research and development (R\&D) took place in Europe, however efforts in market innovation and entrepreneurship need to be improved for the EU to rank above its competitors. The venture capital available in the EU was only $20 \%$ compared with that of the US. ${ }^{19}$ In order to reach the full potential of the single market in today's environment, the market should be designed to fit the digital age supporting jobs, innovation, competition and investment. Digitally driven new economic and business models need to be developed to create sustainable growth for a transforming and value-added economy.

\section{B. Digital Europe for Economic Recovery}

Digitization for economic recovery has been very important for Europe as the EU started attaching importance at high technology developments for innovative and sustainably growing EU, since the 2000's. Taking this infrastructure as an opportunity, the EU has been following a smart route for the digital future of Europe in order to meet future challenges. The progresses made by the EU, gained much more importance as a need for an economic supplement to increase the healing effects of conventional

18 EU Commission, "The 2021-2027 Multiannual Financial Framework: Digital shines through in the EU's long-term budget”, 2019, Accessed:20.06.2020.

https://ec.europa.eu/digital-single-market/en/2021-2027-multiannual-financialframework-digital-shines-through-eus-long-term-budget

19 Robert Atkinson, Michael Mcternan and Alastair Reed, edited, Sharing in the Success of Digital Economy, (Rowman and Littlefield, 2015),71-77. 
political formulas. Although the works done on the digital transformation are obvious, they should all be proven by indicators systematically.

The single market is one of the important drivers of the EU integration, enabling the free movement of persons, goods, services and capital (four freedoms). More than 60 years of experience has been visioned to boost economic growth by easing the opportunities. As a supplementary to such challenges, the Single Market Strategy released in 2015 aims to reveal the full potential of the single market and boost the competitiveness, being aware of the digital technologies transforming the world. The EU stressed that "Digital Single Market (DSM)" is the one of the most important measures of the EU's Single Market Strategy. Thereby, creating digitally connected Europe is a priority for providing people with new opportunities; as four freedoms are not yet satisfactorily fulfilled in the digital world due to some barriers. ${ }^{20}$

In this context, the target has been keeping economic activities with a strong industrial base, handling important topics such as connectivity, ecommerce, data economy, media-copyright, trust, e-government and removal of technical barriers as important tools.

The process, started with DSM initiative, continued with "Digital Europe" programme increasing the scope and effectiveness of the digitization of the economy and also securing the digital Europe. The Commission proposed the programme, for the Multiannual Financial Framework (2021-2027), which focuses on the strategic digital capacities of the EU and on facilitating the wide deployment of digital technologies. Overall budget of $€ 9.2$ billion is assigned for shaping and supporting the digital transformation of Europe's society and economy. ${ }^{21}$

Now the focus is on the new European target "Fit for the Digital Age" which is timely for economy bearing upon pandemic resulted in the launching of Digital Services Act. The EU is aiming to make the digital transformation work for people and businesses, encouraging new technologies by gaining trust via actions designed by EU's strategies for artificial intelligence (AI), data and industrial strategy. In line with this purpose, in February 2020 communication on the "Shaping Europe's Digital Future" was launched by the EU Commission for re-shaping the digital

${ }^{20}$ European Commission, "European Dimensions of the digital economy", 28 Sept 2018, Accessed: 01.10.2020, https://ec.europa.eu/digital-single-market/en/blogposts/europeandimension-digital-economy

21 European Commission, "Europe investing in digital", 2019, Accessed: 20.09.2020. https://ec.europa.eu/digital-single-market/en/europe-investing-digital 
transformation tools by inclusive use of last version digital technologies. Its approach is based on three pillars, technology for all, competitive and fair digital economy, open and sustainable society. ${ }^{22}$ The White Paper on Artificial Intelligence and European Data Strategy are the absolute musts of the strategy. Along with such measures, on March $10^{\text {th }} 2020$, new small and medium sized enterprises strategy for sustaining the digitization of small and medium sized enterprises was also released ${ }^{23}$ which breathes life into economy and employment.

Digital Services Act has been made ready for September 2020, with the goal of reinforcing the single market for digital services and helping provide smaller businesses with legal clarity and level playing field they need. The goal will be adding value to people's lives. In order to improve functioning of the Single Market, Internal Market and Consumer Protection Committee (IMCO) took the initiative to prepare a legislative report with recommendations to the Commission on a Digital Services Act and organized a workshop on "E-Commerce rules fit for the digital age" during which member of parliaments discussed with experts, stakeholders and consumer protection organizations, possibilities of efficient reforms of regulation and consumer protection in online marketplaces in the EU. In addition e-commerce which is the cornerstone of the Internal Market for the last twenty years should be improved upon recommendations of IMCO on a "Digital Services Act."

\section{How Digital is Europe?}

Steps taken on the way of digitization, with a proper timeline starting from the DSM, has had valuable contributions on achieving the goal of Digital Europe. On the first days of COVID 19, as mentioned above, the EU Commission launched the "White Paper on Artificial Intelligence" and a "European Strategy for Data" proving the importance of digital transformation and adapting to real life as if it were a groundwork for socially distanced pandemic era. The strategy was focused on technology serving people's lives, AI contributing to innovation and competition. Additionally, while designing Europe as a leader model, it was planned to assure the data security, accessing the online goods easily and safely, easing the opportunities rising from digitalization for individuals and firms. Data

22 European Commission, "Shaping Europe's Digital Future”, Accessed: 20.09.2020, https://ec.europa.eu/info/strategy/priorities-2019-2024/europe-fit-digital-age/shapingeurope-digitalfuture_en\#three-pillars-to-support-our-approachn

23 "Shaping Europe's Digital Future". 
and AI, two important factors of the strategy were planned to contribute to the innovativeness of specific sectors such as agriculture, security, health and production. In the context of the EU's one of the most important digital priorities "A Europe Fit for the Digital Age" the roles of the topics boosting digital transformation were attached great importance. All these works have also been key milestones for the completion of DSM. The fundamentals shaping the digital economy in the EU are considered to be collecting data and increasing investments. That the COVID 19 was announced as "pandemic" by the WHO, proved the correctness and well-timing of the processes done by the EU in the aftermath of the actions and steps taken in this field.

\section{A. The Digital Economy and Society Index (DESI)}

Regulations on the digital journey of the EU are obviously expressing the intentions of the member states. Along with such regulations making a way for important innovations and transformations, the need to assess the achievements requires objective tools which lead to the creation of indexes and tests inevitably.

The EU has designed an index to gauge digital performances of the EU countries. The DESI ${ }^{24}$ of the EU monitors the overall digital performance of the EU by tracking the EU countries' performances individually. It is composed of five fundamental policy areas including connectivity, human capital, use of internet, integration of digital technology and digital public services which exhibit important results on the overall performances of EU countries' digital transformation.

As the COVID crisis has an important impact on economic behaviors of society, DESI 2020 reports are based on 2019 data, depicting the conditions of digital economy and its reflections to society prior to the pandemic. With these indicators, an important measurement has been taken in the context of manageability of economic recovery. Besides the Commission's efforts, actions taken by member states individually are very important to measure the digital capabilities and promote digital inclusion.

${ }^{24}$ The Digital Economy and Society Index (DESI) is a composite index published annually by the European Commission since 2014. It measures the progress made by EU Member States towards a digital economy and society, bringing together a set of relevant indicators, DESI, (2020):3, Accessed: June 2020-10-22, https://ec.europa.eu/digital-singlemarket/en/desi 
Figure 1 shows each EU country's digitization level compared within the context of the fundamental policy areas. According to this analysis, Finland, Sweden, Denmark and Netherlands are the most digitized countries nevertheless Italy, Romania, Bulgaria and Greece need to speed up the improvement of the policies for digital transformation. The overall performance would have been higher if the largest economies of the EU, (in terms of GDP), such as Germany and France were the leading digitalized countries. On the other hand, Germany ranks the $1^{\text {st }}$ amongst all with the $5 \mathrm{G}$ readiness, placing emphasis on advanced digitization. Although Italy needs improvements regarding the field, the strategy entitled "Italy 2025" is displaying the aim and enthusiasm of the country for a radical transformation putting the innovation and digitization at the core. ${ }^{25}$. These investments and initiatives are representing targets and commitments of EU countries on the way to "Digital Europe", the necessity of which has been perceived during the pandemic.

Figure 1: Digitization Levels of EU Countries

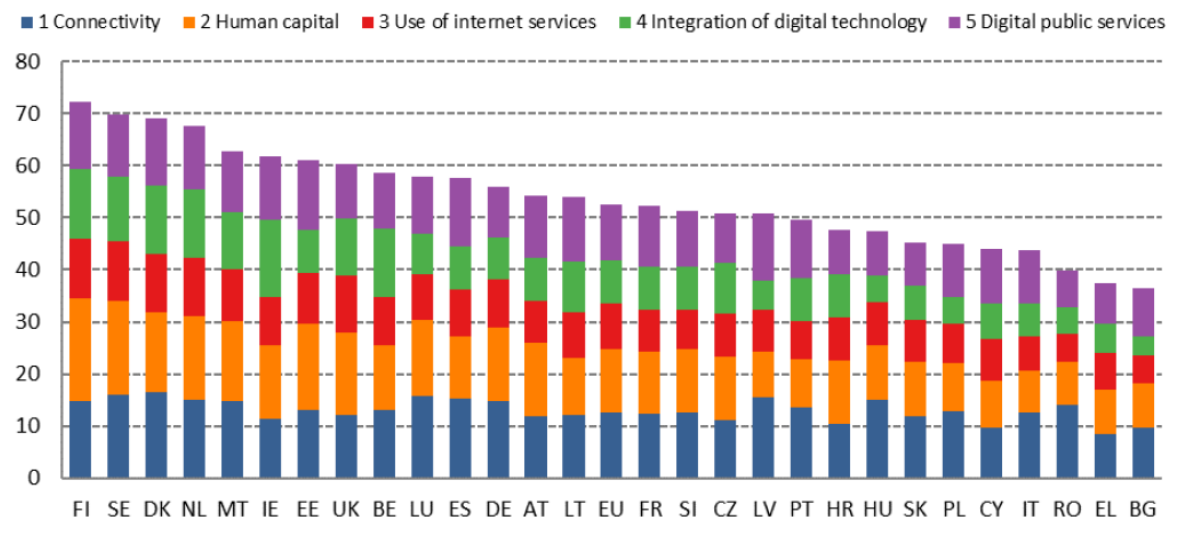

Source: DESI, https://ec.europa.eu/digital-single-market/en/desi .

The data on the UK are also included in the figure since the UK was still a part of the EU at the time of launching of the index.

Within the EU, varying levels of digitization of countries implies the need to put forward important tools to maintain homogeneity. Also

25 “DESI 2020”, 14. 
comparison of EU countries with other digitized countries worldwide is very important in order to analyze the EU's global digital performance and stimulate competition. The international DESI (I-DESI), in figure 2, gives an idea on the position of the EU amongst other big economies in the context of digitization. Comparison is made in five policies determined above in the first figure. According to this figure, the EU is standing on the average below the desired level for competing in global economy. It was the year 2000, with the Lisbon Strategy, when the EU had first declared its ambition for sustainable development supporting high-tech, innovative production and research and development, acknowledging its stationary economy. Early attempts could have earned the EU a solid ranking. On the other hand, the situation is not so dramatic, as it is systematically working on the way to narrow the gap.

Figure 2: International DESI

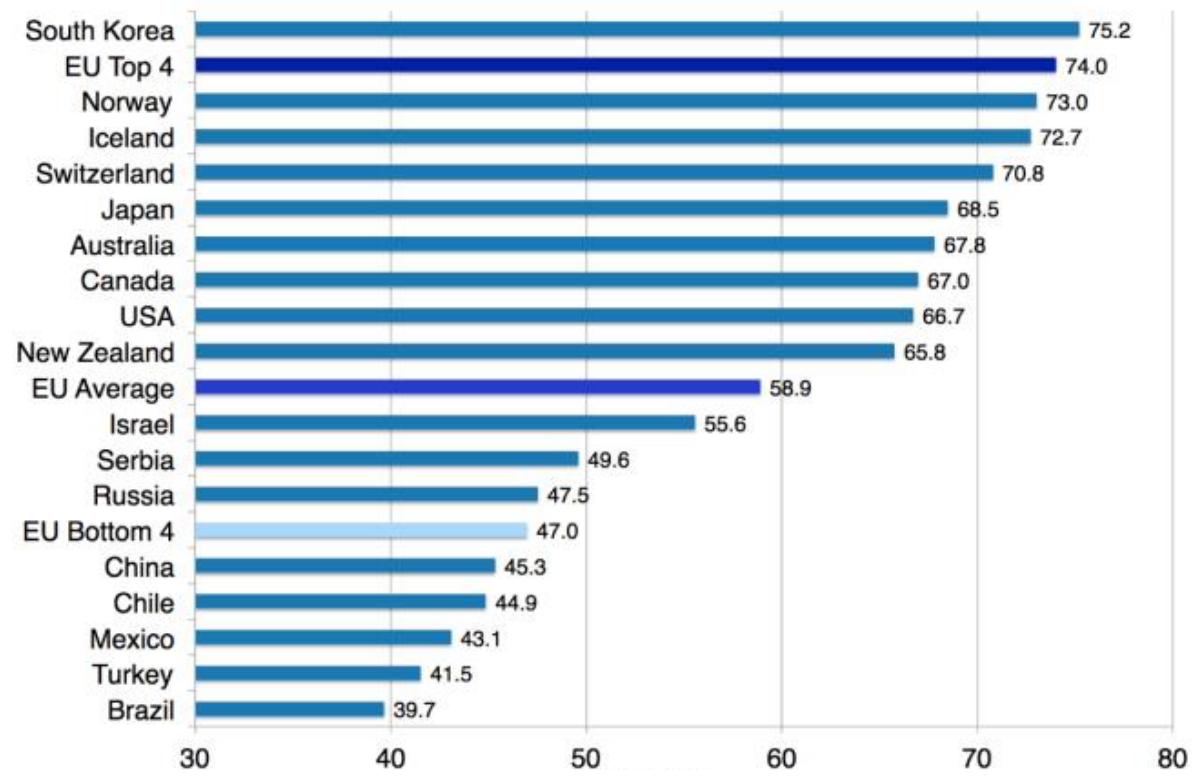

Source: https://ec.europa.eu/digital-single-market/en/news/how-digital-europecompared-other-major-world-economies 


\section{B. Economic Recovery}

Apparently, digital transformation is perceived as one of the most important tools to exit from the economic crisis called into being by the pandemic. The recovery indicators produced by DESI, give a healthy review for resilient digital transformation and economic recovery. These are; very high capacity networks (VHCN) and 5G, digital skills, advanced digital technologies for businesses and digital public services are very important and compulsory tools for stronger digital transformation and ease economic recovery.

First of all, VHCN and 5G technology are of great importance to catalyze the fast growing internet usage. Currently $44 \%$ of households benefit from VHCN, others still use basic broadband infrastructure. Malta, Denmark and Luxembourg score the highest with $90 \%$. In 2016 5G action plan for Europe launched by the Commission, targeted the end of 2020 for the completion of the process. At the moment, 17 member states have assigned $5 \mathrm{G}$ spectrum.

Digital skills of the citizens are also very substantial for healthy digitization. In the EU $85 \%$ of the citizens use internet however it does not depict good skills in digital reading. The percentage of really skilled users increased only 3 percent from 2015 to 2019. Development of the digital skills of the society will add to the process. Also the improvement of businesses in all sectors is very crucial especially in times of crisis where economic recovery is necessary. It would obviously be made easier by the using digital technologies such as internet of things, AI, cloud computing, big data analysis which enhances the productivity and improves efficiency for recovery.

In the figure 3 below, usage of two important tools; cloud services and big data in the EU by company size are compared. It is obvious that large enterprises are more prone to the usage of new generation methods. 
Figure 3: Cloud services and big data usage in the EU by company sizes.

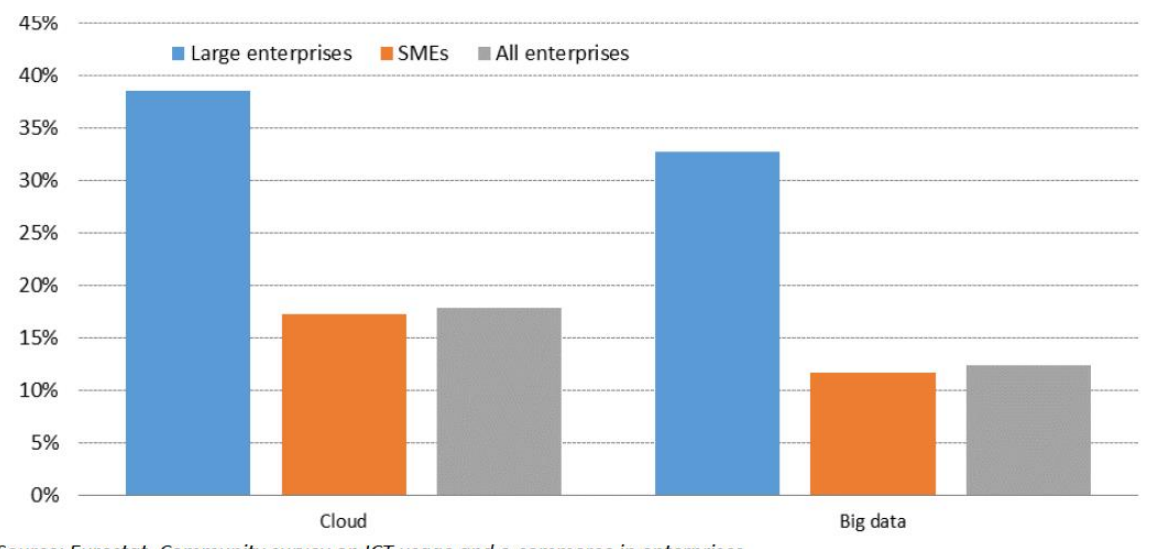

Source: Eurostat, Community survey on ICT usage and e-commerce in enterprises.

Increasing the competitiveness of businesses and improving the services by integrating the digital technologies surely opens up new doors for new developments. Digital technologies such as electronic information sharing, social media, big data and e-commerce are also likely to keep their importance for a long time in most of the sectors which would make the economies recovered and improved.

Last but not least, the usage of digital public services during pandemic should also be mentioned. Socially distanced lifestyle made inevitable the supply of public services through advanced technologies. EU supply of public services are above the average in terms of other recovery tools and the gap between the highest ranking country Estonia (89 \%) and the lowest Romania $(50 \%)^{26}$.

Macro-economic analysis of McKinsey and Company is an important test for digital response of the EU in economic recovery period. According to the analysis by McKinsey and Company to test the efficiency of digital transformation with new technologies such as AI and advanced robotics, comprehensive analysis and survey on new disruptive digital technologies were executed encompassing simulation of macro-economic impact of the digital transformation. The study had tested two scenarios;

Base scenario, measuring the effects of digital technologies without new technologies. According to this scenario, between 2017 and 2030

26 "DESI 2020", 15-17. 
annual $11 \%$ GDP increase has been estimated with a 14,1\% GDP increase by 2030 in the EU.

In a simulated scenario (including $\mathrm{AI}$ and advanced robotics) EU would achieve a $10 \%$ increase by 2023 and 17,4 \% GDP improvement by $2030 .{ }^{27}$

This outcome has proved the usage of new and up to date technologies to be prerequisite for the efficient usage of digital tools in order to boost economic growth. Apparently the EU has been taking valuable steps for digital infrastructure and regulations, been very important in economic slowdown in pandemic. What about the future scenarios of $\mathrm{EU}$ in giant, competitive new economy.

Dramatic comparison between China, US and EU show that China is dominating the global funding for AI startups with $48 \%$, US is following with $38 \%$. Others including the "EU" has a portion of $13 \%{ }^{28}$ Top 3 AI patent holder firms are IBM, Microsoft and Google with 3594, 2207, and 1174 patent families respectively. ${ }^{29}$ This race proves that, new innovative technologies and AI startups should be given utmost importance in the EU as well.

What the EU is doing in this field is also nonignorable. The EU is also boosting public and private investment and fostering skills in the field. Europe started to finance AI related researches in 2004. Over the duration of Horizon 2020, 2.6 billion Euros have been reserved for AI funding, 700 billion Euros for robotics and 27 billion Euros for developing skills. Also, European Strategy on AI is fostering investments to reach 20 billion Euros for 2018-2020, and for each year after 2020, expecting an average 20 billion Euros investment per year. ${ }^{30}$

27 European Commission, "Shaping the digital transformation in Europe - Working paper: Economic potential", (19 February 2020):1,3, Accessed: 20.05.2020.

https://ec.europa.eu/digital-single-market/en/news/shaping-digital-transformation-europeworking-paper-economic-potential

28 Vincent, James, China overtakes US in AI startup funding with a focus on facial recognition and chips, Accessed: 15.09 .2020 https://www.theverge.com/2018/2/22/17039696/china-us-ai-funding-startup-comparison

29 Top AI Companies: the leaders, 2020, Accessed: 15.09.2020. https://www.datamation.com/artificial-intelligence/top-artificial-intelligencecompanies.html\#ai-leaders

${ }^{30}$ Trustworthy AI brocure, Serptember 2019, Accessed: 20.09.2020. https://ec.europa.eu/digital-single-market/en/news/trustworthy-ai-brochure 


\section{Conclusion}

Digitalization is a magic key for many, perceived as providing new opportunities for entrepreneurship, generating income, shaping consumer choices, easing government services. Additionally, it has been a rescue tool on the days of the pandemic both for economic transactions and social networking. It has allowed people to shop, trade, chat, innovate and boost the economic vitality. With respect to producers, cutting costs and scaling across the world have had profound impact on the economy.

The reactions of EU to the enormous changes in the last decades such as technological changes and digitization and their reflections to the economic world have been a major subject of debate, unearthing 2 questions namely: Is the EU competitive enough in the axis of the global world being shaped by the Industry 4.0 and can the EU manage the new economic system well?

For a long time, after the release of the Industry 4.0, the EU was one step back, probably as a result of protectionist approach to the "novelty". Most common critics about Europe was conservativeness of European companies. Since the invention of internet, nearly 30 years, no European company played a leading role in digital development. A cruel critic of an American researcher about EU's digital transformation was "EU should not copy the US's system, build its own digital DNA. New value creation should be the main target." Apparently, an EU way of digitization is inevitable. ${ }^{31}$ Now the EU has been working on building strong infrastructures with well designed strategies and regulations for digital world. But for comprehensive development, what should be taken into consideration seriously, should be innovativeness and financial supports to AI start-ups which are important for cost-efficient, fast, personal and mutual interaction.

Launching the 2014-2020 Multiannual Financial Framework, brought the idea of DSM with it. It was the milestone of the EU which continued with "Digital Europe" initiatives and increased the speed of digital transformation. Encouraging innovation, rejecting protectionism were the key approaches of the EU's Digital Europe initiative. Global openness paved the way for competition thus taking the advantage of digital transformation more. The actions of the EU on the way of digitization in times of pandemic are promising. The digital tools have been considered as an engine for recovery and positive outcomes. ${ }^{32}$ So it is very clear that important steps on

31 Atkinson, Mcternan, Reed, "Sharing in the Success of Digital Economy", 71-77.

32 Atkinson, Mcternan, Reed, "Sharing in the Success of Digital Economy", 33-38. 
the way for more digital EU were taken which are simultaneously planned to work as a supplementary recovery plan for economic containment of COVID 19 which are also perceived as key approaches for the sustainability of the target of digital Europe. Keeping EU competitive in the face of the global world shaped by the Industry 4.0 is another purpose. The steps taken by the EU for managing the new economic system are promising, on the other hand they should be fastened and strengthened by maintaining innovativeness and uniqueness.

As a last word, it can be said that, concerning latest developments in the fields of digitization and COVID 19 spreading the whole world, "infecting" the economy entirely and making things come to a halt, digitalization has showed up as the magic key that makes the flow of life possible. Therefore, the EU has made digital Europe agenda a priority both in the containment of COVID 19 crisis and in the designation of the future of the EU. Having said that, future challenges lead economies to be digitized and competition takes place in the area of digitization. In this respect, the EU is taking the right path consistent with its future direction. Fastening and deepening the innovative approaches of an EU way of digitization are supposedly the keys to the EU's future.

\section{Bibliography}

Atkinson, Robert, McTernan, Michael and Reed Alastair, edited, "Sharing in the Success of Digital Economy", Rowman and Littlefield, 2015.

Baldwin, Richard, De Mauro, Beatrice, edited, "Mitigating the COVID Economic Crises", (2020), Accessed: 15.05.2020, https://www.researchgate.net/publication/342961959_Mitigating_the_COVID_ Economic_Crisis_Act_Fast_and_Do_Whatever_It_Takes_A_VoxEUorg_Book

Brinca, Pedro, Duarte, Joao B., Casto, Miguel Faria, Is the Covid 19 Pandemic a supply or a demand shock?, 20.05.2020 :( 1-2), Accessed: 10.09.2020, https://papers.ssrn.com/sol3/papers.cfm?abstract_id=3612307

European Commission, "European Dimensions of the Digital Economy", 28 Sept 2018, Accessed: 01.10.2020, https://ec.europa.eu/digital-singlemarket/en/blogposts/european-dimension-digital-economy European Commission, "Europe Investing In Digital", 2019, Accessed: 20.09.2020. https://ec.europa.eu/digital-single-market/en/europe-investing-digital

European Commission, "International Digital Economy and Society Index (DESI)" https://ec.europa.eu/digital-single-market/en/news/how-digital-europecompared-other-major-world-economies ,Acessed:June 2020-10-22 
European Commission, "Shaping Europe's Digital Future”, Accessed: 20.09.2020, https://ec.europa.eu/info/strategy/priorities-2019-2024/europe-fit-digitalage/shaping-europe-digitalfuture_en\#three-pillars-to-support-our-approach

European Commission, "Summer 2020 Economic Forecast", Accessed: 10.08.2020, https://ec.europa.eu/commission/presscorner/detail/en/ip_20_1269

European Commission, "Shaping the Digital Transformation in Europe - Working Paper: Economic Potential", (19 February 2020):1,3, Accessed: 20.05.2020. https://ec.europa.eu/digital-single-market/en/news/shaping-digitaltransformation-europe-working-paper-economic-potential

European Commission, "The Digital Economy and Society Index (DESI)" https://ec.europa.eu/digital-single-market/en/desi , Acessed:June 2020-10-22

European Commission, "The 2021-2027 Multiannual Financial Framework: Digital Shines Through in the EU's Long-Term Budget", 2019, Accessed:20.06.2020. https://ec.europa.eu/digital-single-market/en/2021-2027-multiannual-financialframework-digital-shines-through-eus-long-term-budget

European Economic and Social Committee, "Ask the President", Accessed:11.07.2020, https://www.eesc.europa.eu/en/about/politicalorganisation/eesc-president/ask-the-president

Fernandes, "Economic Effects of Coronavirus Outbreak (COVID-19) on the World Economy", March 22, 2020, Accessed:August 2020, https://papers.ssrn.com/sol3/papers.cfm?abstract_id=3557504

Kılıç, Kemal, Marin, Dalla, "How COVID 19 is Transforming the World Economy", (2020), Column 10 May, Accessed: 10.08.2020, https://voxeu.org/article/how-covid-19-transforming-world-economy Marinko, Jurcevic, Mostarac, Vinko, Lukso, Lulic, "The Digital Transformation of Croation Economy Compared with Other EU Countries", Preliminary Communication, Accessed: 10.08.2020, https://search.proquest.com/docview/2422403017?pq-

origsite $=$ gscholar\&fromopenview $=$ true

Ozili, Peterson, Arun, Thankom, "Spillover of COVID 19: Impact on the Global Economy", SSRN Electronic Journal, 2020, Accessed: 20.07.2020, https://www.researchgate.net/publication/340236487_Spillover_of_COVID19_impact_on_the_Global_Economy Top AI Companies: The Leaders, 2020, Accessed: 15.09 .2020 . https://www.datamation.com/artificial-intelligence/topartificial-intelligence-companies.html\#ai-leaders.

Trustworthy AI Brochure, September 2019, Accessed: 20.09.2020. https://ec.europa.eu/digital-single-market/en/news/trustworthy-ai-brochure.

UNCTAD, "2019 Report on Digital Economy”, (2020), Accessed: 12.09.2020, https://unctad.org/system/files/official-document/der2019_en.pdf 
Vincent, James, China Overtakes US in AI Start Up Funding With A Focus On Facial Recognition And Chips, Accessed: 15.09.2020. https://www.theverge.com/2018/2/22/17039696/china-us-ai-funding-startupcomparison. 